\title{
Farm Gate Dairy Milk Marketing Channel Choice in Kericho County, Kenya
}

\author{
Ngeno Elijah Kiplangat ${ }^{1}$, Ngeno Vincent $^{2}$ \\ ${ }^{1}$ Department of Applied Economics, School of Economics, University of Eldoret, Eldoret, Kenya \\ ${ }^{2}$ Department of Agricultural Economics and Resource Management, Moi University, Eldoret, Kenya
}

Email address:

engeno489@gmail.com (N. E. Kiplangat)

\section{To cite this article:}

Ngeno Elijah Kiplangat, Ngeno Vincent. Farm Gate Dairy Milk Marketing Channel Choice in Kericho County, Kenya. Journal of World Economic Research. Vol. 7, No. 3, 2018, pp. 92-104. doi: 10.11648/j.jwer.20180703.11

Received: September 28, 2018; Accepted: November 5, 2018; Published: November 30, 2018

\begin{abstract}
This study examined the factors that determined dairy farmer households' choice of a commercial milk marketing channel in Kericho County, Kenya. Multistage cluster sampling technique was employed in collecting data from 432 dairy farmers and survey data was analyzed using multivariate probit regression model. Marginal effect results revealed that a unit change in household's pasture farm size and partnership in lobbying for better milk price increased the probability of selling milk only to commercial milk buyer by one and 19 percentage points respectively. The number of cows milked per day and milk storage/cooling raised the probability of selling raw milk to commercial buyers by 2.3 and 16.1 percentage points respectively. Commercial milk buyers valued security in raw milk supply which came from trusted relationships and from contracts with the dairy milk seller households. To increase the choices of commercial dairy milk marketing channels and hence the switching power of the dairy farmer households in Kericho County and by extension, Kenya as a whole, this study recommends strengthening the capacity of dairy farmer households by up scaling their technical knowhow and by enlarging their herd sizes. Further, the study recommends group formation, partnership development and increased financial investments in livestock milk markets by national and county governments.
\end{abstract}

Keywords: Raw Dairy Milk, Farm Gate, Marketing Channel, Multivariate Probit Regression

\section{Introduction}

Agricultural markets in developing countries, including Sub-Saharan Africa (SSA), are undergoing rapid changes in response to strong economic growth, improved infrastructure and communication systems, and growing demand among consumers for higher quality products. Associated with and facilitating these changes are a range of new interventions and investments, from creative ways to finance value chains, to information communication technology (ICT) solutions for the quick and reliable delivery of market information for farmers, to new organizational approaches for linking small farmers to markets [1]. Livestock milk marketing is a favorite sector, where most African governments have chosen to intervene in a variety of ways [2]. These interventions range from outright fixing of wholesale and retail milk prices to monopolizing the export market, yet in many instances policy decisions on livestock milk marketing are often taken in the absence of vital information on how they affect smallscale livestock producers, traders and consumers. While there is some debate about the actual and potential impacts of having a wide array of commercial milk buyers on broader welfare of the rural poor, many case study evidence suggests that farmers are worst placed when faced with a privately owned or government-controlled monopsony[3-4].

In Kenya, milk marketing is composed of many agents that are either formal or informal. Informal milk markets continue to dominate over the formal markets by absorbing most of the milk from smallholder farmers and they account for over 80 percent of the total milk sold [5]. However, different milk marketing channels yield different profit margins and these markets provide valuable opportunities for rural and urban employment [6]. Market oriented smallholder dairy production normally offers significant source of income for smallholder farmers and profitability of dairy production depends on market prices upon which, a good marketing system is thus very crucial. There exist a number of milk 
marketing channels to smallholder dairy farmers which offer different farm gate milk prices. Moreover, these commercial milk markets are unable to satisfy both the producer's and the consumer's needs. On one hand, the producers are only interested in getting the highest possible return for their milk output sales; while on the other hand, milk consumers want the best quality milk for the prices they offer [7]. However, one of the most controversial issues in international development is that of the rise in modern milk marketing chains, especially under private ownership, that could have negative effects on the producer's income distribution [8]. Several research findings have opined that the poor will continue to suffer from this process. However, a lot of debate has been on-going in countries such as India, although it is of no consequence to the Kenyan dairy sector.

Smallholder dairy farming in most cases is an informal family business that mainly utilizes family labor and employs one or two hired workers, thus making their operations micro and small enterprises (M.S.E) which hardly enjoy the economies of scale [9]. Smallholder dairy farmers fulfil numerous functions in the agricultural economy, which includes food security, equitable distribution of income and creation of employment opportunities especially to the rural poor, thus making the sector an important economic driver [10]. Dairy farmers, as agents of economic growth, would be expected to graduate their operations to medium sized enterprises through expanded dairy herd size, the use of modern technologies, advanced operating skills, diversified portfolio of dairy products brought about by processing activities, and the use of appropriate marketing channels [11].

Since the liberalization of the dairy industry in Kenya in 1992, new institutional arrangements in milk collection, processing and marketing have emerged to help both the producers and the buyers. At farm gate level in Kericho County, informal commercial milk marketing channels dominate the market segment, with most of dairy farmer households using them. These commercial milk marketing channels include hawkers, brokers, self-help groups (SHG) as well as neighbours and business establishments like restaurants and milk bars. The informal milk marketing outlets have been shown to absorb most of the raw milk from smallholder farmers, and they account for over 70 percent of the total raw milk output sold in the county [12]. The cooperative societies, self-help groups and direct milk sales to processors are considered as the formal milk marketing channels, and they absorb approximately 30 percent of the total raw milk sold. Most of the raw milk output that was collected and purchased by co-operative societies and registered self-help groups was sold in the informal milk market outlets in the county. However, New Kenya Cooperative Creameries (New KCC) and Brookside Dairies Limited controlled 44 and 20.8 percent respectively of the processed milk market share in Kenya [12].

Dairy cooperative societies in the county, which used to be an integral part of the formal milk collection and marketing, have been relegated to buyers of the last resort due to the low raw milk purchase prices that they offer. These cooperatives societies have been marketing a big proportion of their milk output directly to the processors and urban milk markets within the county. However, farm gate raw milk prices offered by the various milk buyers have been fluctuating periodically to levels that have been too low and hardly coverthe dairy farmers' costs of production [12]. In February and March, 2014, New KCC and Brookside Dairy processors, as the dominant milk buyers, delayed farmer's payment for raw milk delivered to them due to their unsold milk stocks. They also lowered significantly their farm gate raw milk purchase prices. New KCC reduced her farm gate raw milk purchase price to Kenya Shillings (KSh.) 32 per liter from KSh.40, while Brookside lowered her milk purchase price to KSh.30 from KSh. 35 and 40 in March and February, 2014 respectively [13]. This shows that by end of March 2014, New KCC had lowered her farm gate milk price payments by 20 percent while Brookside Dairies had lowered by 14.3 and 25 percent by March and February, 2014 respectively.

Despite the fact that smallholder farmers face difficulties in marketing, they continue to produce and survive in the face of unfavourable conditions some of which can be solved through use of trusted milk marketing channels [14]. Farmers also maximize their returns on investments through value addition, which compliments their own produce from other sources, as well as offering diversified products from the same material inputs. When selling their products, such farmers will make use of marketing channels that enable their produce to reach the market at least cost per unit of output. By pooling skilled manpower, dairy farmers who are chain actors, are able to minimize on transaction costs, access market information and adhere to government regulations more easily. Dairy farmers are able to take collective action by securing new milk markets, bargaining for better prices for milk and milk products and use of the most effective marketing channels. Such actions are always taken against a background of strong associations by farmers who are trained and have a strong entrepreneurial orientation. However, farmers' welfare depend mostly on the price received for their output in environments of minimal agricultural policy support, the absence of social safety nets, and a weak nonfarm rural economy which limits agricultural diversification [15]. These features characterize much of Kericho County, where rural poverty has been widespread. Farm gate milk price received by the dairy farmer households for their daily milk output from the various commercial milk marketing channels has also been of considerable concern. Though evidence shows that farm gate milk prices have often been significantly variable and vary considerably between milk producers, the latter has been attributed to uneven competition caused by weak physical and commercial infrastructure [16]. Poor physical and commercial/institutional infrastructure raises transport and transaction costs and increases the likelihood of incomplete priceformation [17-20]. Therefore, dairy farmersare less likely to be aware of the prices that are received by other dairy farmers from the numerous commercial milk buyers in 
areas where there is weak physical and commercial infrastructure, a problem that was also inherent in the study area. This is also another reason why milk processors and other commercial milk buyers may have acted as local monopolists. Government intervention through erratic rent seeking may have also reinforced these problems. There has also been a deficiency of information on the dominant milk marketing channel and particularly in terms of financial incentives to the dairy farmer households from the dairy enterprise. Most studies have sought to establish dominance premised on the proportion of the populace that use a certain marketing channel as opposed to using net returns [21-22]. Other previous research interventions to promote the dairy industry have mainly focused on the opportunities in dairy the sector, factors affecting dairy productivity, competitiveness of milk processing firms and intensification of dairy farming, other studies have focused on productivity, genetics, nutrition, and value chain development [22-27]. However, knowledge gap still exists in literature on determinants of farmers' choice of a milk marketing channel and the reasons for use or no use of these marketing channels. Therefore, by considering the relationship that existed between farmers' milk marketing channel choice and raw farm gate marketed milk output sold to commercial milk buyer, this study attempted to determinethe choice of a given milk market channel by dairy farmer households in Kericho County, Kenya. The study also addressed the counterfactual queries that are important in forecasting the impacts of policy changes brought by the farmer's choice of a milk marketing channel in the county of study.

\section{Methodology}

\subsection{Research Design}

This study was conducted in Kericho County, Kenya using cross-sectional and correlational survey research designs. A total of 432 dairy farmer households were sampled and used in the study.

\subsection{Sampling Procedure and Sample Size}

The study employed multistage cluster sampling procedure to get the total population and sample size of Interest. The County was clustered into six sub-counties, and to achieve a representative sample size, the six sub-counties formed the first-stage cluster. Within the six sub-counties, second-stage cluster sample of wards and villages with high concentration of small scale dairy farmers was then selected. Sample selection of dairy farmer households from the clustered wards was then done using random sampling. Effort was also made to include statistically significant sub-samples of dairy milk producers representing the different milk marketing channels and the different sizes of each of the sub counties.

The sampled milk producing $n^{\text {th }}$ smallholder dairy farmer household was determined by the proportionate size sampling methodology as shown in (1) and as adopted from [30].

$$
N_{0}=\frac{Z^{2} p q}{e^{2}}
$$

Where $N_{0}$ is the sample size, $Z$ is the standard normal value of 1.96 significant at 5 percent confidence level, $e$ is themargin of error, $p$ is the estimated population proportion of dairy farmers with characteristics of interest, $q=1-p, Z=$ 1.96 , and $e=$ degree of precision. The sample units were calculated proportionately based on the number of dairy farmer households in each sub county and as a proportion of the total dairy farmers in the county against the desired sample size of 504 as shown in table 1. Based on the above mentioned criteria, the random sample of dairy farmer households selling raw milk to different milk marketing channels was set for the whole county consisting of 75 farmers from Kipkelion East, 63 from Kipkelion West, 91 from Belgut, 44 from Ainamoi, 81 from Soin/Sigowet and 150 from Bureti. After data cleaning, 432 observations remained for analysis. The sample was then subdivided into two groups of dairy farmer households; firstly, those who sold milk directly to the final consumers through the local commercial markets and informal sales and secondly, those that only sold milk to a commercial buyer.

Table 1. Proportionate Distributions of Dairy Farmer Households.

\begin{tabular}{lllll}
\hline Sub - County & Number of Households & Number of Dairy Farmers & Percentage & Total proportion $\left(N_{0}\right)$ \\
\hline Kipkelion East & 27,791 & 13,996 & 15 & 75 \\
Soin/Sigowet & 20,940 & 15,141 & 16 & 81 \\
Belgut & 31,394 & 17,111 & 18 & 91 \\
Bureti & 30,977 & 28,304 & 30 & 150 \\
Ainamoi & 27,700 & 8,150 & 8 & 44 \\
Kipkelion West & 14,615 & 11,725 & 12 & 63 \\
Total KerichoCounty & 153,417 & 94,427 & 100 & 504 \\
\hline
\end{tabular}

\subsection{Data Types}

Given the objective of identifying the determinants of dairy farmer households' choice of a milk marketing channel, the population of interest was defined as the primary dairy farmer households' who sold raw dairy cow's milk at farm gate to another supply chain actor. For that reason, dairy farmer households without any dairy cow, those who did not sell any of the raw milk produced or those who processed all the milk themselves at household level were not included in the study. Therefore, given this restriction, its uniqueness, the sample for this study could not be directly compared with the 
county or national official data on the general structure of milk production.

Data types used encompassed representative sample of dairy farmer households representing the various categories of households, types of commercial and non-commercial milk marketing channels and changing structure of dairy sector. To analyze the response of the smallholder milk producers, the study categorized the choice of milk marketing channels into a binary outcome, whether the dairy farmer household sold milk at farm gate to commercial milk marketing channels $\left(Y_{I}\right)$ and if farmer household chose to sell also to final consumers (non-commercial channel) or otherwise $\left(Y_{0}\right)$. Commercial milk marketing channel was taken to mean three major marketing channels: organized milk cooperative societies, organized private sector milk buyers, and traditional/unorganized milk buyers. Data collected included dairy farmers' socio-economic characteristics, actual milk production, milk market competitiveness and other related obligations with the milk buyers. The farm production data comprised of the size of land under dairy production, average volume of milk produced per day, amount of livestock inputs and farm gate milk prices and prices of other livestock outputs.

Respondents were also expected to provide information regarding market competitiveness and estimated total number of potential commercial milk buyers in their respective areas. This would assist in capturing the degree of switching power of each of the dairy farmer household. The study also included data (an independent variable) on whether the farmer sold all the total milk output on contract, on signing agreements or on the spot cash sale. Some farmers may have sold their milk on signing agreements with milk buyers rather than via spot cash sales. The signing of agreements with the milk buyers provided a greater degree of certainty for the buyers regarding the availability of supply, for which a buyer could have paid a premium [31]. Finally, regarding milk marketing characteristics, a dummy variable was introduced that captured on whether or not the dairy farmer household sold milk via milk cooling/chilling plants, milk sheds or milk bars.

\subsection{Analytical Frameworks}

\subsubsection{Theoretical Models}

According to rational choice theory, individual households' rank mutually exclusive alternative decisions in order of utility and they will choose the alternative with the maximum expected utility given their socio-economic and demographic characteristics and relevant resource constraints. Hence, in this study, the producer's milk marketing channel choice that fetched better milk price was conceptualized using a random utility model (RUM). RUM is particularly appropriate for modelling discrete choice decisions such as between marketing channels. It is an indirect utility function where an individual with specific characteristics associates an average utility level with each alternative market channel in a choice set. It is assumed that economic agents, including smallholder dairy farmers, use certain livestock milk marketing systems only when the perceived utility or net benefit from using such a method is significantly greater than is the case without it. Again smallholder dairy farmers are assumed to be rational and they want to derive the highest utility from the choices they make; either to market their farm gate milk produce independently or under a certain commercial milk marketing channel depending on the returns. They make their choices with respect to random utility theory, which states that a decision maker is guided by unobservable, observable and random characteristics when making a decision. Although utility is not directly observed, the actions of economic agents are observed through the choices they make.

The study formulated milk marketing channel selection/choice decision as a two - alternative choice (selling to commercial milk buyer(s) $=1$ and selling to final milk consumer(s) $=0$ ). Let a decision maker (dairy farmer household with raw milk for sale) choose from a set of mutually exclusive alternatives, $\mathrm{j}=1,2, \ldots, \mathrm{J}$. The decision maker obtains a certain level of utility, $U_{i j}$, from each alternative. The discrete choice model is based on the principle that the decision maker chooses the outcome that maximizes the utility. The producer makes a marginal benefit-marginal cost calculation based on the utility achieved by selling to a market channel or to another. His/her utility is not observed, but some attributes of the alternatives as faced by the decision-maker are observed. Hence, the utility is decomposed into deterministic $\left(V_{i j}\right)$ and random $\left(\varepsilon_{i j}\right)$ part:

$$
U_{i j}=V_{i j}+\varepsilon_{i j} ; \forall_{\mathrm{ij}} \in \mathrm{N}
$$

Since $\varepsilon_{i j}$ is not observed, the decision-makers' choice cannot be predicted exactly. Instead, the probability of any particular outcome is derived. The utilities (or the difference between benefit and cost) cannot be observed directly, but the choice made by the producer reveals which one provides the greater utility as reviewed in [32]. A producer selects market channel $\mathrm{j}=1$ if;

$$
U_{i k}>U_{i j} \forall_{\mathrm{j}} \neq k
$$

Where $U_{i k}$ denotes a random utility associated with the market channel $j=k$, and $V_{i j}$ is an index function denoting the producer' average utility associated with this alternative. The second term $\varepsilon_{i j}$ denotes a random error which is specific to a producer's utility preference [33]. Now, suppose that $Y_{i}$ and $Y_{j}$ represent a household's utility for two milk marketing channel choices, which are denoted by $U_{i}$ and $U_{j}$, respectively, then linear random utility model, the milk marketing channel choice, is modelled as shown in (4).

$$
U_{i j}=\beta_{j} X_{i j}+\varepsilon_{i j}
$$

Where $U_{i j}$ is a vector of the milk marketing channel choices $(j=1$ commercial milk buyers; and 0 for final milk consumers) of $i^{\text {th }}$ dairy farmer, $\beta_{j}$ is a vector of channelspecific parameters. $\varepsilon_{i j}$ is the error term assumed to have a 
distribution with mean 0 and variance 1 and identically distributed [32]. $X_{i j}$ is the vector of explanatory variables that determines and or influences the perceived desirability of the choice of the milk marketing channel. Therefore, for the case of choice of a livestock milk marketing channel, if a dairy farmer household decides to use option $j$ marketing channel, it follows that the perceived utility or benefit from option $j$ marketing channel is greater than the utility from other options (say $k$ ) marketing channel depicted in (5) as follows:

$$
U_{i j}\left(\beta_{j}^{1} X_{i}+\varepsilon_{j}\right)>\left(U_{i k}\left(\beta_{k}^{1} X_{i}+\varepsilon_{k}\right), k \neq j\right.
$$

The probability that a dairy farmer household will choose milk marketing channel $j$ among the set of livestock milk marketing channels to market his/her milk instead of the $k$ marketing channel could then be defined as in (6) to (8) below.

$$
P(Y=1 \mid X)=P\left(U_{i j}>U_{i k}\right)
$$

$$
\text { Therefore, } P\left(\beta_{j}^{1} X_{i}+\varepsilon_{j}-\beta_{k}^{1} X_{i}-\varepsilon_{k}>0 \mid X\right)
$$

Hence $P\left(\beta_{j}^{1} X_{i}-\beta_{k}^{1} X_{i}+\varepsilon_{j}-\varepsilon_{k}>0 \mid X\right)$

$$
P\left(X^{*} X_{i}+\varepsilon^{*}>0 \mid X=F\left(\beta_{j}^{*} X_{i}\right)\right.
$$

Where; $P$ is a probability function, $U_{i j}, U_{i k}$, and $X_{i}$ are as defined above, $\varepsilon^{*}=\varepsilon_{j}-\varepsilon_{k}$ is a random disturbance term, $\beta_{j}^{*}=\left(\beta_{j}^{1}-\beta_{k}^{1}\right)$ is a vector of unknown parameters that can be interpreted as a net influence of the vector of independent variables influencing the choice of a milk market, and $F\left(B^{*} X_{i}\right)$ is cumulative distribution function of the error terms $\left(\varepsilon^{*}\right)$ evaluated at $B^{*} X_{i}$. The exact distribution of $F$ depends on the distribution of the random disturbance term, $\varepsilon^{*}$. Depending on the assumed distribution that the random disturbance term follows, several qualitative choice models can be estimated [32].

The choice of a commercial milk marketing channel that offered good milk price at farm gate was fundamental and important decision for the dairy farmer household where many other factors and conditions had to be considered as a basis for precise decision. Consistent with the theoretical model, the study assumed that dairy farmer households practiced dairy farming with the aim of receiving a fair and reasonable milk price and income maximization, to smooth household income through market guarantee (despite prevailing liquidity constraints) and for market access and production volume utility, while others practiced dairy farming just only for prestige. Therefore, the model for the dairy farmers' commercial milk marketing channel choice was modelled based on random utility theory, and that dairy farmer households preferred certain commercial milk marketing channels to others even though some were not even profitable channels. Liquidity preference also played a major role in dairy farmers' decision for particular commercial milk marketing channel choice.

\subsubsection{Econometric Analysis}

Building on the random utility framework and accounting for selection bias, the decision to choose a commercial milk marketing channel choice or not was based on farm and farmer characteristics. Therefore, probit model being one of the most widely used members of the family of generalized linear models in the case of binary dependent variables was used. In probit models, the link function relating the linear predictor $\eta=x \beta$ to the expected value $u$ is the inverse normal cumulative distributions function $\left(\Phi^{-1}(u)=\eta\right)$. Two of the more widely used frameworks was adopted [34]. The first is the specified joint multivariate link function for the multiple binary responses. For example, the bivariate probit model described in [35] can be written as in (9).

$$
\begin{gathered}
P\left(Y_{i, j}=1 \mid x_{i, j}\right)=\Phi\left(\eta_{i, j}\right), j=1,2 \\
\left.P\left(Y_{i, 1}=1, Y_{i, 2}\right)=1 \mid x_{i, j}\right)=\Phi_{2}\left(\eta_{i, 1,} \eta_{i, 2}, \rho\right),
\end{gathered}
$$

Where $\Phi_{2}$ is the bivariate standard normal cumulative distribution function, and $i$ and $j$ index respondents and dependent variables respectively.

The econometric analysis consisted of multivariate probit model that was used to estimate the factors that determined the milk marketing channel choice equation, specifically whether farmers sold milk only to a commercial milk buyer or they also sold to final consumer. The study assumed that it was likely that the characteristics of small scale dairy farmer who sold milk only to a commercial milk buyer differed from those who sold also to final consumers. However, selection effect or bias correction factor exists in cross sectional data since farmers themselves decide whether or not to sell to a particular milk marketing channel [29]. Consequently, those who sold and those not could differ systematically, leading to non-random selection bias.

The parameter estimates of the probit model were only used to provide the direction of the effect of the independent variables on the dependent (choice) variable; thus the estimates represented neither the actual magnitude of change nor the probabilities (being simply the values that maximized the likelihood function). Probit regression coefficients were used to estimate the marginal effect $\left(\phi\left(Z_{Y}\right)_{Y_{\mathrm{j}}}\right)$ of choosing commercial milk buyer(s) by the dairy farmer household for each predictor, while holding all other variables in the model at their means. They gave the change in the $z$-score or probit index for every one unit change in the predictors [32]. Assuming the errors $\varepsilon_{i j}$ are independently and identically distributed with an extreme value distribution, the probability that alternative $j$ is chosen from $n$ alternatives can be represented by a mathematical model as formulated in (10).

$$
\operatorname{Pr}\left(Y_{i}=\mathrm{j} \mid \mathrm{x}_{\mathrm{i}}\right)=\frac{e^{\beta_{j}^{\prime} x_{i}}}{1+\sum_{K=1}^{J} e^{-\beta_{k}^{\prime} x_{i}}} \text { forj }=0,1, \ldots, J, \beta_{0}=0
$$


Equation(10) provides a set of probabilities for $J+1$ choice for a decision maker with characteristics $x_{i}$ while $Y$ denotes choices. Marketing channels $x$ is a $1^{*} \mathrm{k}$ vector with first element unity and $\beta_{j}$ is a $k * 1$ vector with $j=1 \ldots J$. Prob $\left(Y_{i}=\right.$ $\left.j \mid x_{i}\right)$ is determined once the probabilities for all $j=1,2, \ldots, J$ are known and the probability must sum up to unity. For the parameter estimates to be consistent and unbiased, it requires that the probability of using one choice by a given farmer be independent of the probability of choosing another choice. Therefore, the following model in (11) was specified for milk marketing channel choice analysis [15].

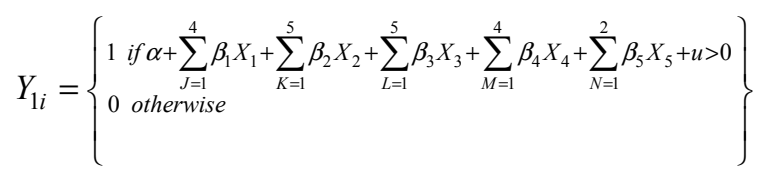

Where; $Y_{l i}$ is a binary variable, a dependent variable, for stage one analysis, which takes the value one if the farmer sold to commercial milk buyers only and zero if the farmer decided to sell also to final consumers of milk, that is, the dependent variable is the framers' choice for a given marketing channel); $X_{i}$ is a vector $\left(X_{1}-X_{5}\right)$ of observable control covariates; $\alpha$ and $\beta$ are the parameters that were estimated, and $u$ is the random error term, which included unobserved individual effects. In this case, an individual is assumed to have preferences defined over a set of alternatives. The choice (dependent) variable had more than two unranked/unordered options while the independent variables consisted of features/attributes of the alternatives and characteristics of the dairy farmer respondents. The model was preferred since it permitted the analysis of decision across the two categories in the dependent variable therefore making it possible to determine choice probabilities of the channels. Several factors were hypothesized to influence smallholder dairy farmer household's choice of a given commercial farm gate milk marketing channel. The choice of these explanatory variables was mainly based on the general working hypothesis and partly on empirical findings from literature, and therefore, a positive or negative sign was assigned depending on the potential influence of a particular variable on choice of a milk marketing channel.

\subsection{Diagnostic Tests for Multivariate Probit Model}

Diagnostic tests were conducted from the regression results of STATA output. All assumptions were tested and corrected accordingly. Potential multicollinearity among explanatory variables was tested in a preliminary analysis. They were found not to have any potential influence on estimates from the model. The highest pair-wise correlation was 0.4 whereas multicollinearity is a serious problem if pair-wise correlation among regressors is in excess of 0.5 [36]. An analysis of variance inflation factor (VIF) did not show any problem since none of the VIF of a variable exceeded 8 [32]. In addition, the likelihood ratio chi-square test statistic of 48.89 with a $p$-value of 0.001 indicated that the model that was used in the study as a whole was statistically significant as shown in Table 6. Further, to test for goodness of fit, log likelihood, Cox and Snell, McFadden Adjusted $\mathrm{R}^{2}$, and Nagelkerke Adjusted $\mathrm{R}^{2}$ results of 0.107 , 0.082 , and 0.143 respectively were less than 20 percent. This showed that the multivariate probit model that was used in the study fitted the outcome results well.

\section{Results and Discussion}

\subsection{Characteristics of Dairy Farm Households}

Table 2 shows the analyzedresults for the sampled dairy farmer households. As shown, dairy farmer households were divided into three groups: those who sold raw milk directly to final consumers via farm gate sales, those that only sold to a commercial milk buyer (milk processor, or other milk intermediary actor) and those that sold to both final consumers as well as commercial buyer(s) via local markets and informal sales. Results of the study show that majority of the dairy farmer households owned one or two dairy milking cows with existence of significant differences in the distribution of dairy farmers across the six sub-counties. The median herd size was about 3 milking cows per household, whereas, fifty five percent of the dairy farmer households sold milk to commercial buyer(s), 40 percent to final consumers while 4 percent sold to both commercial buyer(s) and final consumer(s) respectively. From the results, most of the dairy farmer households sold their farm gate raw milk to more than one milk marketing outlet depending on the unit price offered, volume of milk produced, and the urgency of need for cash.

Table 2. Milking Cows per Farm Unit and by Type of Milk Marketing Channel.

\begin{tabular}{|c|c|c|c|c|}
\hline Number of milking cows & Sold only to commercial buyer(s) & Sold to final consumer(s) & $\begin{array}{l}\text { Sold to both final consumers and } \\
\text { commercial buyer(s) }\end{array}$ & Total \\
\hline 1 & 54 & 72 & 4 & 130 \\
\hline 2 & 104 & 53 & 3 & 160 \\
\hline 3 & 30 & 32 & 4 & 66 \\
\hline 4 & 22 & 7 & 6 & 35 \\
\hline 5 & 12 & 4 & 1 & 17 \\
\hline $6-9$ & 9 & 3 & 2 & 14 \\
\hline $10-19$ & 6 & 2 & 1 & 9 \\
\hline Above 20 & 1 & 0 & 0 & 1 \\
\hline Total & 238 & 173 & 21 & 432 \\
\hline Mean $=2.6$ & $\mathrm{SD}=3.1$ & Minimum $=1$ & Maximum $=50$ & \\
\hline
\end{tabular}


Table 3 presents results on the total number of potential commercial buyers of raw milk at farm gate for the surveyed dairy farmer households and the mean farm gate milk price offered by the various commercial milk marketing channels on the farm's total milk output in the county. Results revealed that five commercial raw milk buyers existed in the study area namely; New KCC, Brookside Dairy Limited, milk traders/vendors, self-help groups and milk cooperative societies that owned the milk cooling/chilling plants. From the results, 181 dairy farmer households sold milk to milk traders/vendors. In return, milk traders bought milk at farm gate at a price of Ksh. 36.80 per liter per day on average from the surveyed dairy farmer households selling only to commercial milk buyers. They offered a mean minimal and maximum price of Ksh. 25 and Ksh.60 per liter per day, respectively. Milk cooling/chilling plants bought milk from only 61 of the surveyed dairy farmers while milk buying selfhelp groups bought from only 8 dairy farmer households at an average of Ksh.33.34 and Ksh.37.5 per liter per day, respectively. Though, farmer's membership to cooperative societies and other farmer groups such as self-help groups assisted dairy farmers to acquire credit and inputs and sell their milk in the county, farmers perceived their output prices not to have been good.

Table 3. Commercial Farm Gate Milk Buyers.

\begin{tabular}{llllll}
\hline Commercial farm gate milk buyer & No of Observations & Mean price per liter & Standard Deviation & Minimum & Maximum \\
\hline New KCC & 9 & 34.78 & 7.10 & 30 \\
Brookside & 14 & 33.93 & 7.32 & 27 \\
Traders/vendors & 181 & 36.76 & 7.49 & 50 \\
Milk buying Self-help groups & 8 & 37.5 & 5.35 & 65 \\
Milk cooling/chilling plants & 61 & 33.34 & 6.67 & 30 \\
Total & 273 & & & \\
\hline
\end{tabular}

\subsection{Determinants of Milk Marketing Channel Choice}

Table 4 presents the first multivariate probit estimated coefficients that showed factors that influenced dairy farmer household's milk marketing channel choice decision. The parameter estimates of the choice model results only provided direction of the effects of the predictor variables on milk marketing channel choice. The estimates in table 4 represented neither the actual magnitude of change nor the probabilities. The coefficients had no direct interpretation. They were simply the values that maximized the likelihood function. The results therefore, revealed that age, farming experience, pasture farm size, distance to milk market, number of milking cows, daily milk yield, number of calves, milk price, partnership in lobbying and partnership in milk cooling and storage were all significantly different from zero. The null hypothesis that determining factors for milk marketing channel had no significant influence on the choice decision made by small holder dairy farmer household was therefore rejected. Further, from the results findings, all the coefficients had the expected sign except age, distance to milk market, number of milking cows and milk price.

Table 4. Multivariate Probit Estimates of the Milk Marketing Channel Choice.

\begin{tabular}{|c|c|c|c|c|}
\hline Variable & Coefficient & Standard Error & t-Statistic & Prob. \\
\hline Age & -0.012287 & 0.004940 & -2.487418 & $0.0133 * *$ \\
\hline Education level & -0.023667 & 0.025456 & -0.929711 & 0.3531 \\
\hline Farming experience & 0.018557 & 0.006688 & 2.774757 & $0.0051 *$ \\
\hline Farm size & -0.006882 & 0.005402 & -1.273852 & 0.2034 \\
\hline Pasture farm size & 0.022113 & 0.012640 & 1.749421 & $0.0010^{*}$ \\
\hline Permanent employees & 0.093037 & 0.057400 & 1.620853 & 0.1058 \\
\hline Distance to milk market & -0.021267 & 0.008725 & -2.437401 & $0.0152 * *$ \\
\hline Number of milking cows & -0.048104 & 0.018186 & -2.645083 & $0.0085 *$ \\
\hline Number of heifers & 0.005487 & 0.006153 & 0.891692 & 0.3731 \\
\hline Daily milk yield & 0.051921 & 0.024023 & 2.161288 & $0.0313 * *$ \\
\hline Number of calves & 0.039357 & 0.018373 & 2.142137 & $0.0328 * *$ \\
\hline Milk price & -0.019040 & 0.006164 & -3.088784 & $0.0021 *$ \\
\hline Partnership in lobbying & 0.514052 & 0.177623 & 2.894052 & $0.0040^{*}$ \\
\hline Partnership in milk marketing & -0.257644 & 0.152711 & -1.687135 & $0.0923 * * *$ \\
\hline Partnership in milk cooling/storage & 0.432722 & 0.157238 & 2.752013 & $0.0062 *$ \\
\hline Technical extension services & 0.062251 & 0.064438 & 0.966056 & 0.3346 \\
\hline Sought for extension service & 0.000913 & 0.182501 & 0.005003 & 0.946 \\
\hline Constant & 1.832133 & 0.494418 & 3.705637 & $0.0002 *$ \\
\hline Fitted $^{\wedge} 2$ & -1.394250 & 0.697313 & -1.999461 & $0.0462 * *$ \\
\hline Log likelihood (LogL) & 546.170 & & & \\
\hline LR Chi-square (19) & 48.888 & & & $0.001 *$ \\
\hline Pseudo R-Squares & & & & \\
\hline
\end{tabular}




\begin{tabular}{|c|c|c|c|c|}
\hline Variable & Coefficient & Standard Error & t-Statistic & Prob. \\
\hline Cox and Snell & 0.107 & & & \\
\hline $\begin{array}{l}\text { McFadden Adjusted } R^{2} \\
\text { Nagelkerke Adjusted R }\end{array}$ & $\begin{array}{l}0.082 \\
0.143\end{array}$ & & & \\
\hline
\end{tabular}

Legend

$*=1$ percent, $* *=5$ percent, $* * *=10$ percent level of significance, respectively.

$p$-value of Likelihood Ratio Test $\left(\operatorname{Pr}>\mathrm{x}^{2}\right)$

Table 5 shows the output results for the second multivariate probit model. Estimated marginal effects coefficients were used to measure the expected change in probability of particular choice of a milk marketing channel with respect to a unit change in an independent variable from the mean. The marginal effects were evaluated using the sample means of all variables. The parameters of the model were interpreted as effects on the probability of selecting a particular commercial milk marketing channel of an infinitesimal change in each independent continuous variable and the discrete change in the probability for dummy variables [31].

The average marginal effects for the multivariate probit model estimates revealed that the signs of the marginal effect variables were in line with the signs obtained from the parameter estimates in table 4 . The marginal impacts of the dummy variables, surprisingly statistically significant variables, on probability of choosing a commercial milk marketing channel had fewer impacts in magnitude than that of the original parameter estimated impacts in table 4 results. Results presented in table 5 shows that the predicted probability of choosing a commercial milk buyer by the dairy farmer household was positive and significant with farming experience, pasture farm size, number of milking cows, daily milk production per cow, partnership in lobbying, partnership in milk cooling/storage, technical extension, and if the dairy farmer households had sought for extension services. Milk price per liter per day and distance to milk market negatively determined the choice of a milk marketing channel. However, the two were statistically significant variables.

Table 5. Marginal Effects Estimates of the Milk Marketing Channel Choice.

\begin{tabular}{|c|c|c|c|c|}
\hline & Margin (dy/dx) & Standard Error & $\mathbf{Z}$ & $\mathbf{P}>|\mathbf{z}|$ \\
\hline \multicolumn{5}{|l|}{ Farmer Characteristics } \\
\hline Age & -0.005391 & 0.0031269 & -1.72 & $0.085^{* * *}$ \\
\hline Education level & -0.012238 & 0.0238845 & -0.51 & 0.608 \\
\hline Farming experience & 0.007544 & 0.0034747 & 2.17 & $0.030 * *$ \\
\hline Off-farm employment & -0.003981 & 0.0495347 & -0.08 & 0.936 \\
\hline \multicolumn{5}{|l|}{ Farm characteristics } \\
\hline Farm size & -0.003502 & 0.0052763 & -0.66 & 0.507 \\
\hline Pasture farm size & 0.009505 & 0.0127257 & 0.75 & $0.005 *$ \\
\hline Permanent employees & 0.036931 & 0.0516336 & 0.72 & 0.474 \\
\hline Casual workers & 0.014797 & 0.034318 & 0.43 & 0.666 \\
\hline Distance to milk market & -0.009099 & 0.0060778 & -1.50 & $0.034 * *$ \\
\hline \multicolumn{5}{|l|}{ Herd characteristics } \\
\hline Number of milking cows & 0.022630 & 0.0106186 & 2.13 & $0.033^{* *}$ \\
\hline Number of heifers & 0.020008 & 0.0180197 & 1.11 & 0.267 \\
\hline Number of calves & 0.011861 & 0.0153485 & 0.77 & 0.440 \\
\hline Daily milk per cow & 0.002545 & 0.0032245 & 0.79 & $0.030 * *$ \\
\hline Milk price & -0.007841 & 0.0028144 & -2.79 & $0.005^{*}$ \\
\hline \multicolumn{5}{|l|}{ Partnership } \\
\hline Partnership in lobbying (milk price) & 0.187180 & 0.0702441 & 2.66 & $0.008^{*}$ \\
\hline Partnership milk marketing & -0.047261 & 0.1526948 & -0.31 & 0.757 \\
\hline Partnership in purchasing inputs & -0.003226 & 0.0675515 & -0.05 & 0.962 \\
\hline Partnership in milk cooling/storage/chilling & 0.160995 & 0.0769473 & 2.09 & $0.036^{* *}$ \\
\hline \multicolumn{5}{|l|}{ Extension services } \\
\hline Technical extension service & 0.027963 & 0.0601026 & 0.47 & $0.042 * *$ \\
\hline Sought for extension service & 0.000619 & 0.0476801 & 0.01 & $0.009^{*}$ \\
\hline
\end{tabular}

$*=1$ percent, $* *=5$ percent, and $* * *=10$ percent level of significance, respectively.

$p$-value of Likelihood Ratio Test $\left(\mathrm{Pr}>\mathrm{x}^{2}\right)$

\subsection{Discussion}

\subsubsection{Characteristics of Dairy Farmer Households and Milk Buyers}

In most of the sub counties, selling via milk marketing traders improved significantly the price received by farmers, albeit modestly. These findings were consistent with the rational choice theory $[37,38]$. However, these relationships did not hold for the sub counties where milk marketing cooperatives, especially New KCC and milk buying self help groups were relatively more common. This suggested that commercial milk traders/vendors were more pragmatic, they may have supported the development of milk markets through higher prices they offered, more so in sub counties where they were initially absent and discriminated against dairy farmer households in milk markets only where feasible 
alternatives existed.

\subsubsection{Milk Marketing Channel Choice Determinants}

Farming experience of household head had positive and significant marginal effect on the choice decision for a commercial milk marketing channel. For a one unit increase in the years of experience in dairy farming, the marginal probability of choosing commercial milk buyer increased by 0.8 percentage points, which meant that the general experience of the farmer household increased the marginal value of time. As expected, a dairy farmer seemed to have gained relevant knowledge of milk production and marketing of milk to the milk buying channels through time and hence had an advantage over a new and inexperienced dairy farmer. The dairy farmer households with longer dairy farming experience seemed to observe positive impacts of dairy production as compared with those with fewer years of dairy farming experience.

The size of pasture farm size owned by a dairy farmer household was positively related to the choice of farm gate commercial milk market channel. The marginal effect confirmed that the probability of choice of a commercial milk marketing channel decision increased by 0.95 percentage points as the pasture farm size increased by one acre. This implied that dairy farmers with large pasture land sizes were potentially large milk producers. Further, this result revealed that a dairy farmer who had a large farm size was more likely to sell his or her milk through a commercial milk marketing channel as compared to the farmers with small farm sizes. Dairy farmer households with relatively smaller land holdings and limited access to grazing land could substitute capital for land to produce as much or even higher milk volumes as compared to those with large land holding. Large milk output volumes enabled the smallholder dairy milk producers to switch from one farm gate commercial milk buyer to the other while marketing their milk. This also motivated them to seek out for farm gate commercial milk marketing channels that could accept large quantities of milk supply. On the other hand, this would enhance competition amongst the commercial milk buyers. These results concur with previous findings which recounted that large pasture farm sizes availed more grazing land and increases the farmers' propensity to participate in modern markets. This is because, large farm sizes is considered to be an indicator of wealthier farmers and are expected to produce large volumes of milk implying lower risks in milk marketing [39]. These results are also in convergence with other previous study findings which also found out that farm size had a greater impact on the farmers' decision to join cooperatives in Zhejiang in China [40].

Regarding the estimated change in the number of milking cows, the marginal effect result was positive and statistically significant. This shows that the number of milking cows was associated with an increase in commercial milk marketing channel choices by dairy farmer households. A unit increase in the number of milking cows owned by a dairy farmer household increased the marginal probability of using farm gate commercial milk market channel as compared to using non-commercial milk marketing channels for its milk by 2.3 percentage points. Other studies have reported herd size as being a significant determinant in the milk market channel participation for modern market channels [41]. Herd size is also directly dependent on the pasture land size available for dairy production [41]. Large milk producers were likely to get price incentives or higher prices for their milk deliveries because of high bargaining power as well as lower transaction costs which could be achieved in more organized market channels. The number of dairy cows kept by the dairy farmer households determined the total production costs and therefore influenced the amount of working capital needed on the farm. This would force dairy farmer households with large herd size to supply their milk to commercial milk marketing channels that handle big volumes and pay the whole lump sum milk revenues for continuous running of their dairy operations.

As expected, average milk yield per cow per day was statistically significant and had positive marginal influence of 0.25 percentage points on the choice of a commercial milk marketing channel. This shows that the per day marketable milk surplus increased in response to an increase in the number of milking cows and also with the number of available milk marketing channel choices. This also shows that the variable significantly affected the farmers' milk marketing channel choice decision. Large number of milking cows determines the volume of milk available for sale, which is confirmed by earlier research findings, where a positive relationship exists between volume of milk produced per day and the choice of cooperatives marketing channel [41]. This could be due to the cost reduction on the side of cooperatives especially on transport where the cooperative collects milk from its members from collection centers. Spatial distribution of small producers will have implications on the cooperative society's operating costs and the inference for these results therefore, is that dairy farmers who produce fewer liters of milk could simply sell to vendors at farm gate to avoid transport costs. However, previous studies have found the that large milk producers normally get price incentives because of their high bargaining power as well as their lower transaction costs [42]. They further report that the total cost of production is determined by the total herd size that is kept by the dairy farmer.

Lobbying for better milk prices had a positive marginal influence of 18.7 percentage points on the probability of the choice of a milk marketing channel by the dairy farmer household and it was significant at one percent probability level. This shows that collective action improved the choice decisions of milk producers and consequently, this helped the dairy farmer households to sell their milk output with ease to the various milk buyers which also include the dairy cooperative societies. Essentially, partnership in lobbying for better milk price enhanced access to price information which eventually led to increased farmer household likelihood of selling milk to commercial milk marketing channels. Therefore, partnership in the milk marketing systems has 
relatively little to do with the provision of marketing channel facilities, but rather with the role and volumes held by the individual marketers [43].

Results on partnership in milk storage, cooling and or chilling had a positive marginal effect of 0.16 units on the probability of smallholder dairy farmer's choice of a commercial milk marketing channel. This meant that if a dairy farmer was a member of farmer's group, association or cooperative, $\mathrm{s} /$ he was 16 percentage points likely to choose a commercial milk marketing channel. The relationship was much stronger in the case of dairy farmer milk marketing cooperative societies, which showed the strength of the dairy cooperative society. These results therefore, revealed that majority of the dairy farmer households produced milk individually but came together to store; cool and chill milk in the cooperative society's milk cooling/chilling plants, since the economies of scale in their daily dairy milk production was practically absent. They also came together to market milk mutually, since economies of scale in milk marketing and processing were quite important to them. The success of any milk cooperative society in milk marketing is assessed in terms of improving milk output prices based on the right milk marketing channel choice decision they make. Collective action would enable the small dairy farmers to attain better bargaining power, economies of scale, and reduced transaction costs in their production processes [15]. Thus, partnership in milk cooling/storage was crucial in raising the dairy farmer household income and improving their food security status in the study area.

Technical extension service and whether the dairy farmer household had sought for extension service had positive marginal effects on choice of a commercial milk marketing channel by the sampled smallholder dairy farmer households at $5 \%$ and $1 \%$ significance levels respectively. The marginal increase in the level of technical extension services provided by the national and county governments and on whether a dairy farmer household had sought for extension service increased the probability of using farm gate commercial milk marketing channel by 2.8 and 0.06 percentage points respectively. These results were in convergence with other previous study findings that found out that extension service is one of the crucial determinants of agricultural productivity [44]. Other studies have found positive relationship between extension contacts and on-farm trials for the adoption of new technologies $[45,46]$. While extension contact provides farmers with knowledge about the benefits to be realized from technologies adopted, contact with new a technology, either through on-farm trials or extension agents, can be expected to stimulate increased production leading to improved farm incomes[47].

\section{Conclusions and Recommendations}

From the study results, dairy farmer households' choice of a milk marketing channel in Kericho County, Kenya is influenced by a number of factor relationship characteristics which in general increased significantly the marginal effects on the choice decision for the commercial milk marketing channel. The study shows that farm gate milk price per liter per day offered by a commercial milk buyer is important in determining the choice of a milk marketing channel. Likewise, the ability to make the milk buyer and the dairy farmer relationship to be closer and thereby contributing to the development of solutions that better serve the needs of both the seller and the buyer is yet another. This is corroborated by the majority dairy farmer households that partnered in lobbying for better milk prices and in milk cooling, storage and chilling of milk by the milk cooperative societies, a potentially useful role that milk marketing partnership play. From literature, farmer groups are considered to operate profitable milk market units where small farmers organize themselves in collecting, processing and marketing of milk and milk products. Similarly, membership to a farmer group significantly determined participation in the modern commercial milk marketing and markets. Farmer organizations such as cooperative societies which does milk cooling/chilling and storage are very vital in market acceptance and involvement because they enable farmers to make essential savings. These savings and investments helps the dairy farmer households to obtain high quality of milk produce, access to financial resources, knowledge on good farming practices and milk marketing information, and enable them to venture into new technologies.

In order to increase the choices of milk marketing channels and hence the switching power of the dairy farmer and which leads to increased marketed milk output volume, efforts should be geared towards strengthening the capacity of existing small and medium-scale farmers in Kericho county. They should be encouraged to enlarge their herd sizes through up-scaling farmer technical know-how and encouraging enclosed dairy grazing systems. To achieve these, the county and national governments should get involved by reducing the transaction costs through institutions interventions, improving milk quality and safety through capacity building of smallholder milk producers through extension programs and improving milk marketing infrastructure.

\section{Acknowledgements}

The paper is an extract based on the author's $\mathrm{PhD}$ work at the Department of Agricultural Economics and Resource Management, Moi University, Kenya. I would like to thank my university supervisors, anonymous reviewers and the editor for their helpful comments and suggestions on this article.

\section{Conflict of Interests}

The authors declare that they have no competing interests. 
Table 6. Multicollinearity Analysis of Continuous and Discrete Variables using Variance Inflation Factor.

(Objective one Variables)

\begin{tabular}{lll}
\hline Variable & VIF & 1/VIF \\
\hline Farming experience & 2.70 & 0.370466 \\
Age of Household head & 2.65 & 0.377335 \\
Pasture farm size & 2.38 & 0.419698 \\
Number of heifers & 2.06 & 0.485726 \\
Total farm size & 2.03 & 0.491877 \\
Partnership in milk marketing & 1.84 & 0.543615 \\
Partnership in milk production & 1.83 & 0.547116 \\
Partnership extension & 1.68 & 0.595362 \\
Number of calves & 1.57 & 0.637532 \\
Full time employees & 1.42 & 0.702753 \\
Partnership in milk processing & 1.40 & 0.715283 \\
Partnership in milk storage/cooling & 1.38 & 0.723117 \\
Education Level of household head & 1.24 & 0.806499 \\
Off farm Employment & 1.20 & 0.833275 \\
Daily casual workers & 1.13 & 0.882488 \\
Distance to milk market & 1.07 & 0.937304 \\
Sought for Extension services & 1.06 & 0.945389 \\
Milk Price & 1.05 & 0.954050 \\
Number of milking cows & 1.04 & 0.958191 \\
Daily milk production & 1.04 & 0.966042 \\
Mean VIF & 1.58 & \\
\hline
\end{tabular}

Objective two Variables

\begin{tabular}{|c|c|c|}
\hline Variable & VIF & 1/VIF \\
\hline Number of milking cows & 1.38 & 0.724038 \\
\hline Number of farm gate commercial buyers & 1.04 & 0.964631 \\
\hline Percentage of total milk output sold via New KCC & 1.15 & 0.869408 \\
\hline Percentage of total milk output sold via Brookside & 1.11 & 0.897656 \\
\hline Percentage of total milk output sold via milk Traders & 1.11 & 0.902263 \\
\hline Percentage of total milk output sold via Self-help groups & 1.07 & 0.935448 \\
\hline Percentage of total milk output home consumption & 1.04 & 0.961643 \\
\hline Percentage of total milk output sold via milk cooling/chilling plants & 1.02 & 0.981222 \\
\hline Trust & 1.04 & 0.963466 \\
\hline IM Ratio & 1.41 & 0.706992 \\
\hline Mean VIF & 1.14 & \\
\hline \multicolumn{3}{|l|}{ Objective three Variables } \\
\hline Variable & VIF & 1/VIF \\
\hline Age of household head & 2.54 & 0.394266 \\
\hline Gender of household head & 1.05 & 0.956489 \\
\hline Total Household Members & 1.04 & 0.965747 \\
\hline Education Level of $\mathrm{HH}$ & 1.19 & 0.837556 \\
\hline Farming experience of $\mathrm{HH}$ & 2.53 & 0.395965 \\
\hline Formal Employment & 1.18 & 0.846315 \\
\hline Number of milking cows & 1.03 & 0.974372 \\
\hline Number of calves & 1.06 & 0.944016 \\
\hline Milk Price per liter & 1.06 & 0.944193 \\
\hline Distance to Milk Market & 1.03 & 0.969059 \\
\hline Sought for Ext. service & 1.03 & 0.968429 \\
\hline Access to credit & 1.03 & 0.974339 \\
\hline Access milk market information & 1.04 & 0.959261 \\
\hline Milk market participation & 1.05 & 0.950164 \\
\hline Mean VIF & 1.27 & \\
\hline
\end{tabular}




\section{References}

[1] ILRI, (2011). Towards priority actions for market development for African farmers. In Proceedings of an international conference, Nairobi, Kenya,13-15 May 2009 (p. 400). Nairobi, Kenya. Retrieved from http://mahider.ilri.org/handle/10568/16491.

[2] Beneberu T. K., Girma A. H., 2011. Determinants of Sheep Prices in the Highlands of Northeastern Ethiopia: Implication for sheep value chain development. Addis Ababa.http://doi.org/10.1007/s11250-011-9837-x.

[3] Gorton, White J., (2007). Transformation and contracting in the supply chains of the former Soviet Union. In: Swinnen, JFM. (Ed.), Global supply chains standards and the poor: how the globalization of food system and the standards affects rural development and poverty. CABI, Wal. J.F.M. (Ed.). Belgium: CABI. pp: 175-187.

[4] Sadler M., (2006). Comparative analysis of cotton supply chains in Central Asia. In: Swinnen, J.F.M. (Ed.), Case studies on vertical co-ordination in Agrofood Chains in Europe and Central Asia, ECSSD. Washington, DC: World Bank.

[5] Karanja, A. M., (2003). The Dairy Industry in Kenya: The post-liberalization agenda Tegemeo Agricultural Monitoring and Policy Analysis (TAMPA II) Project, by USAID, Nairobi.

[6] Thorpe W., Muriuki H. G., Omore A., O. M. O. and S. S., (2000). Dairy Development in Kenya: The Past, thepresent and the future. "Challenges to Animal Production in the New World Order. Nairobi, Kenya.

[7] Muriuki H. G., (2011). Dairy Development in Kenya. How smallholder dairy systems in Kenya contribute to food security and poverty alleviation: results of recent collaborative studies. FAO, Rome.

[8] Elizabeth, M. Farina, M. and T. R., (2000). Agrifood grades and standards in the extended Mercosur: Their role in the changing Agrifood system. American Journal of Agricultural Economics, 82(5), 1170-1176.

[9] GoK, (2012). Kenya National Dairy Master Plan. A situational analysis of the dairy subsector. Nairobi: Government Printer, Kenya

[10] Dorosh, P.A. and H. Steven, (2003). Growth linkages, price effects and income distribution in Sub-Saharan Africa. Journal of African Economies, 12(2): 207-235.

[11] Ortner, K.M., J. Hambrusch and J. Kirner, (2000). The efficiency of dairy farms in Austria. Do natural conditions matter? Vienna: Federal Institute of Agricultural Economics.

[12] Kenya Dairy Board (KDB), (2015). The Kenyan dairy industry at a glance. http://www.kdb.co.ke/

[13] Business Daily, (2014). Kenya Dairy Board plans to regulate raw milk prices, p. 12. Nairobi. Retrieved from http://www.businessdailyafrica.com/Corporate-News/Kenya.

[14] Jari, B., (2009). Institutional and technical factors influencing agricultural marketing channel choices amongst smallholder and emerging farmers in the Kat River Valley. African Journal of Agricultural Research, 4(11): 1129-1137.
[15] Sauer J., Gorton, M. and White, J., (2012). Marketing, cooperatives and price heterogeneity: Evidence from the CIS Dairy Sector. Agricultural Economics, 43(2), 165-177. http://doi.org/10.1111/j.1574-0862.2011.00574.x.

[16] Kazmer, D.R., Konrad, M., (2010). Economic lessons from the transition: The basic theory re-examined. ME Sharpe, Armonk.

[17] Striewe L., (1999). Grain and oilseed marketing in Ukraine, In Swinnen, J.F.M. (Ed.), Global Supply Chains Standards and The Poor: How the globalization of food system and the standards affects rural development and poverty. Iowa State University Ukraine Agricultural Policy Project (UAPP). Kiev: CABI, Wal. J.F.M. (Ed.). pp: 175-187.

[18] Gow H. R, Swinnen J. F. M. (2001). Private enforcement capital and contract enforcement in transitional economies. American Journal on Agricultural Economics, (83 (3)), 686690.

[19] Swinnen J. F. M., (2005). When the market comes to you or not: The dynamics of vertical coordination in Agri-Food chains in transition. Washington, DC.

[20] Liefert W. and Liefert O., (2007). Distortions to agricultural incentives in russia. Agricultural Distortions Working Paper 08, (No. 08). Washington, DC.

[21] Kumar, V. and Staal, J., (2011). Is traditional milk marketing and processing viable and efficient? An empirical evidence from Assam. India. Quarterly Journal of International Agriculture, 49, 2013-225.

[22] Wambugu, S., L. Kirimi and J. Opiyo, (2011). Productivity trends and performance of dairy farming in Kenya. Tegemeo Working Paper No. 43/2011, Tegemeo, Nairobi.

[23] Ahaibwe, G., Mbowa, S. and, \& Lwanga, M. M., (2013). Youth engagement in agriculture in Uganda: Challenges and Prospects. Economic Policy Research Centre, 7(106), 4-20.

[24] Kabunga, N., (2014). Adoption and impact of improved cow breeds on household welfare and child nutrition outcomes: Empirical Evidence from Uganda. Contributed Paper prepared for presentation at the $88^{\text {th }}$ Annual Conference of the Agricultural Economics Society, AgroParisTech, Paris, France 9 -11 April 2014

[25] Kavoi, M.M., Hoag L. and J. Pritchett, (2010). Measurement of economic efficiency for smallholder dairy cattle in the marginal zones of Kenya. Journal of Development and Agricultural Economics, 2(4): 122-137.

[26] Mugambi, D.K., Wambugu S. K., Gitunu A. M. M. and Mwangi M., (2011). Estimation of milk production efficiency of dairy cow farms in Embu and Meru counties of Kenya. Available http://elearning.jkuat.ac.ke/journals/ojs/index.php/jscp.

[27] Murage, A.W. and D. Ilatsia, (2011). Factors that determine use of breeding services by small holder dairy farmers in central Kenya. Tropical Animal Health Production, 43(1): 199-207.

[28] Ng'eno E. K., (2016). Impact of milk marketing channel choice decision on income, employment and breeding technologies among dairy farmer households in Kericho County, Kenya. Asian Journal of Economics and Empirical Research, 3(2): 145-155. 
[29] Anderson D. R., Sweeny J. D., Williams TA, Freeman J and Shoesmith E., (2007). Statistics for business and economics. $9^{\text {th }}$ Edition. Thomson Learning. Thomson Press (India).

[30] Gow H. R., Streeter D. H., and S. J. F. M., (2001). How private contract enforcement mechanisms can succeed where public institutions fail: The case of Juhocukor a.s. Agricultural Economics, 23, 253-265. Retrieved from www.elsevier.com/locate/agecon.

[31] Greene W., (2003). Econometric Analysis (5th Ed.). Upper Saddle River, NJ.: Prentice Hall, Upper Saddle River, NJ.

[32] McFadden D., (2000). Economic Choices. Economic Science. Berkeley, USA.

[33] Fahrmeir, L. and G. T., (2001). Multivariate statistical modeling based on generalized linear models(2nd ed.). New York: Springer.

[34] Ashford, J. R. and Sowden, R. R., 1970. Multivariateprobit analysis. Biometrics 26, 535-46.

[35] Gujarati, (2004). Basic Econometrics. $4^{\text {th }}$ Edition, New York: Tata McGraw Hill Publisher.

[36] Akerlof, G.A. (1970). The market for "lemons": quality uncertainty and the market mechanism, Quarterly Journal of Economics, 84, 488-500.

[37] Morgan, S. B. (2008). Do cooperatives benefit small Guatemalan coffee farmers? The competitive role of guatemalan coffee cooperatives on farm-gate coffee prices, University of San Francisco, mimeo. University of San Francisco.

[38] Hangara, G. N., Teweldemedhin, M. Y., \& Groenewald, I. B., (2011). Measuring factors that can influence cattle supply response to the market in Namibia: Case study from Omaheke communal farmers. Agricultural Extension and Rural Development, 3(8), 141-146.
[39] Larsen, K. A., (2011). Do institutional incentives matter for farmers farmers to join cooperatives: A comparison of two Chinese regions? Journal of Rural Cooperation, 39(1), 1-18.

[40] Tsourgiannis, L., Errington, A. \& Eddison, J., (2002). Marketing strategies of agricultural producers in objective one Greek regions: the factors affecting the selection of marketing channels of sheep and goat producers. Drake Circus, Plymouth, UK.

[41] Sikawa, G.Y. and Mugisha J., (2010). Factors influencing South-Western Uganda dairy farmer's choice of the milk marketing channel: A case study of Kirihura District South Western Uganda. Research Report Series, No. 0856-9681.

[42] McPeak, J., (2004). Contrasting income shocks with asset shocks: livestock sales in Northern Kenya. Oxford Economic Papers, 56(2), 263-284. http://doi.org/10.1093/oep/gpf040.

[43] Odhiambo, B. O., Murage, H., \& Wagara, I. N., (2013). Isolation and characterization of Aflatoxigenic Aspergillus Species from maize and soil samples from selected Counties of Kenya, 7(34), 4379-4388. http://doi.org/10.5897/AJMR2013.5846.

[44] Pope, S. B., (2000). Free shear flows: Turbulent flows. Cambridge: Cambridge University Press. http://doi.org/10.1179/030801801679395.

[45] Studies, N., \& Karimipanah, T., (1996). Turbulent jets in confined spaces application in mixing ventilation experimental and numerical studies. Royal Institute of Technology, Gävle Sweden.

[46] Evenson, R. E. and G. M., (1998). The effects of agricultural extension on farm yields in Kenya (No. 06520-8269). New Haven, Connecticut. 